\title{
Remedies of low performance among Pakistani e-logistic companies: The role of firm's IT capability and information communication technology (ICT)
}

\author{
Waseem Ul-Hameed ${ }^{\mathrm{a}}$, Muhammad Salman Shabbir ${ }^{\mathrm{b}}$, Muhammad Imran ${ }^{\mathrm{b}}$, Ali Raza ${ }^{\mathrm{c}}$ and Rabia \\ Salman ${ }^{\mathrm{b}}$
}

${ }^{a}$ School of Economics, Finance \& Banking (SEFB), Universiti Utara Malaysia, Sintok, Malaysia

${ }^{b}$ School of Business Management (SBM), Universiti Utara Malaysia, Sintok, Malaysia

${ }^{c}$ Othman Yeop Abdullah Graduate School of Business, Universiti Utara Malaysia, Sintok, Malaysia

\section{H R O N I C L E}

\begin{tabular}{l}
\hline Article history: \\
Received February 2, 2018 \\
Accepted June 112018 \\
Available online \\
June 112018 \\
\hline Keywords: \\
e-logistics \\
Staff service quality \\
Website design \\
E-traceability \\
Firm's IT capability \\
Information communication \\
technology (ICT)
\end{tabular}

\section{Introduction}

In the current decade, e-commerce logistic services have increased dramatically (Hameed et al., 2018). E-logistics consists of different tools used by companies accessible through the internet. These tools consist of different electronic platforms, internet portal, electronic catalog, transactions systems, data warehouses, communication tools, and system of offers as well as purchasing and different other software packages for planning, supply chains, digital maps and e-learning systems (Barcik \& Jakubiec, 2012).

\footnotetext{
* Corresponding author

E-mail address: imran.imranb2001@gmail.com (M. Imran)

C 2019 by the authors; licensee Growing Science, Canada doi: $10.5267 /$ j.uscm.2018.6.002
} \begin{abstract}
A B S T R A C T
E-commerce market of Pakistan is instable which causes low performance of e-logistic industry. Thus, logistic industry of Pakistan is lacking as compared to other developing countries such as China, India, and Malaysia. Low performance is majorly based on low staff service quality, inappropriate website design and goods traceability system. As remedies of these issues, the current study introduced firm's IT capability and information communication the primary objective of this study is to investigate the determinants of eapproach along with cross-sectional research design was used. By using the survey method, 300 questionnaires were distributed among the managerial staff of e-logistic companies. Smart PLS 3 was used as a statistical tool. It is found that staff service quality, website design and etraceability had significant and positive relationships with firm's e-logistic performance. Moreover, firm's IT capability as a moderator enhanced the positive effect of staff service quality, website design and e-traceability. Nevertheless, information communication technology (ICT) positively mediated the relationship between e-traceability and firm's elogistic performance. Hence, firm's IT capability and information communication technology key elements to decrease various issues of staff service quality, website design e-traceability. The study is much significant for practitioners and e-logistic companies to enhance performance by focusing on firm's IT capability and information communication technology (ICT).
\end{abstract}


Various studies highlighted the logistic from different prospective (e g., Cichosz et al., 2017; Ha, 2006; Hsu, 2006; Hu et al. 2016; Johan, 2006; Liu et al., 2008), however, in rare cases any study formally carried out the e-logistic firm's performance, particularly in Pakistan. Thus, the current study is one of the attempt to fill this research gap by examining the e-logistic firm's performance in Pakistan.

The e-commerce market of Pakistan is instable and logistic industry experiencing different problems (Shamsi, \& Syed, 2015). Thus, the logistic industry of Pakistan is lacking as compared to other developing countries such as China, India, and Malaysia (Hameed et al., 2018). The most prominent issue in Pakistani logistic industry includes; low staff services quality, inappropriate website design and electronic traceability (e-traceability) of ordered products for customers.

Staff service quality has positive influence on e-logistic (Hua \& Jing (2015). In most of the Pakistani e-logistic companies the services such as attitude, behavior as well as communication is not sufficient to enhance performance. Moreover, website design of companies does not portray the complete information regarding product, price and especially payment system. As the online availability of information increases satisfaction (Peterson et al., 1997), however, non-availability creates dissatisfaction among customers. Nevertheless, traceability of ordered product has also influenced on firm's performance. These issues discourage the customers to buy something through e-logistic. Traceability is basically the process of inquiry about the status of the ordered goods. Improper traceability system in Pakistani e-logistic firms creates disappointment among the customers. All these issues decrease the customers' satisfaction level, which declines the sale and ultimately affects negatively on firm's performance.

However, there is a possibility to overcome all these issues and enhance the e-logistic firm's performance through information communication technology (ICT) and better information technology (IT) capability. Most of the companies are now investing in web-based information traceability system (Campos \& Hardwick, 2006) because it has certain advantages. Thus, the issue of traceability can be handled through information and communication technology (ICT). Nonetheless, firm's IT capability is most significant to manage website in better way which can portray the comprehensive information and e-payment system. Moreover, staff service quality can also be enhanced through firm's IT capability. Thus, in the current study, information communication technology (ICT) is examined as a mediating variable and firm's IT capability as a moderating variable, as shown in Fig. 1.

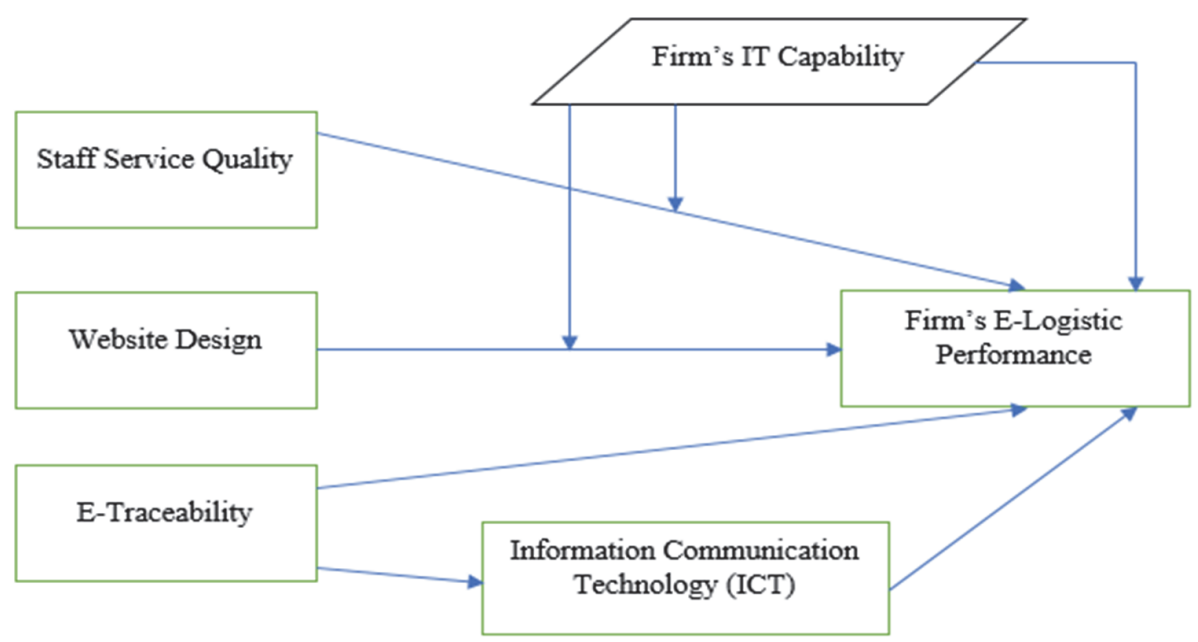

Fig. 1. Theoretical Framework 
The major objective if this study is to investigate the determinants of e-logistic firm's performance in Pakistan. However, to achieve this major objective, the study has the following sub-objectives, as listed below;

1. To examine the role of staff service quality, website design and e-traceability to enhance e-logistic firm's performance,

2. To examine the moderating role of firm's IT capability,

3. To examine the mediating role of information and communication technology (ICT).

Hence, this study contributed in the body of knowledge by filling the gap in literature through firm's IT capability and information communication technology (ICT). This study introduced firm's IT capability as a moderating variable and information communication technology (ICT) as a mediating variable to resolve various issue related to staff service quality, website design and traceability. Thus, the study has key importance for practitioners and e-logistic firms to boost up their performance by developing effective IT capability and information communication technology (ICT).

\section{Review of Literature and Hypothesis Development}

Logistics service representative's attitude, external image of employees, communication with the customer, personalized service and other related contents can have a substantial impact on the perception of e-logistic services. A logistic company's staff service quality with respect to its customer, the image, attitude, and communication help to shape the overall quality (Yuanxiao, 2014). Guarantee to distribute logistics service refers to the enterprise staff's capability to confirm quality services (Benfang \& Feng, 2014).

Definitions of service quality is the result of the comparison that customers make among their expectations about a service and their perception of the way the service has been performed (Lewis \& Booms, 1983; Lehtinen \& Lehtinen, 1982; Parasuraman et al., 1985; Parasuraman et al., 1988; Parasuraman et al., 1994). Lehtinen and Lehtinen (1982) introduced a concept regarding quality. According to this concept, quality depends on output and process, and then in 1983, they introduced the concept of service quality based on physical quality as well as interactive. After that Gummesson and Grönroos (1988) introduced a model for device quality. It has significant impact on customer satisfaction which enhance firm's performance.

According to Thai (2013), service quality is mostly comprising of an attribute. This attribute associated with the staff of the e-logistic company having attitude, external image of employees and communication. The staff service quality generally imitates whether or not the staff instrument, attitude of staff regarding service and communication abilities are effectively meeting the essential quality needs.

Xin and Bo (2004) studied the service quality, its various evaluation standard feature and found that it had significant influence on profitability. Moreover, Hui (2011) performed a study on a network of logistics service for shopping to examine the customer satisfaction index evaluation system. The authors found that different logistics services like attitude are the secondary indexes with respect to the e-logistic customer satisfaction. Thus, staff service quality is the most important element to promote elogistics which automatically enhance firm's e-logistic performance.

According to the results of Hua and Jing (2015), staff service quality has significant and positive relationship with e-logistic customer satisfaction. Thus, staff service quality has vital role in e-logistic practices. It directly influences the customer satisfaction which automatically influence on the performance of various e-logistic companies. Therefore, the above discussion reflects below hypothesis; 
$\boldsymbol{H}_{1}$ : There is a relationship between staff service quality and firm's e-logistic performance.

According to Kim and Lim (2001), information quality has a positive relationship with online customers' satisfaction. However, Kim and Stoel (2004) investigated that appearance of websites and information attribute could influence on customer satisfaction. On the other hand, according to Peterson et al. (1997), online availability of quality information leads to higher levels of customer satisfaction.

It is crucial for electronic businesses (e-logistics) to design better websites with all essential services as well as information to gain trust among customers (Kidane \& Sharma, 2016). According to various studies (see, for example, Daniel et al., 2012; Kim, \& Stoel, 2004; Rana et al., 2014) website and information affect customer satisfaction.

Furthermore, quality of information, system and satisfaction level always influence the use of ecommerce (Pujani, 2011). Additionally, companies should provide better payment system on their websites. This system should be reliable, trustworthy and able to main customer privacy. Because approximately $67 \%$ customers decided to terminate their transactions when they were asked to provide credit card details and personal information (Changchit et al., 2009). Kim et al. (2010) provided a reliable payment system which is adopted by various e-logistic companies as shown in Fig. 2.

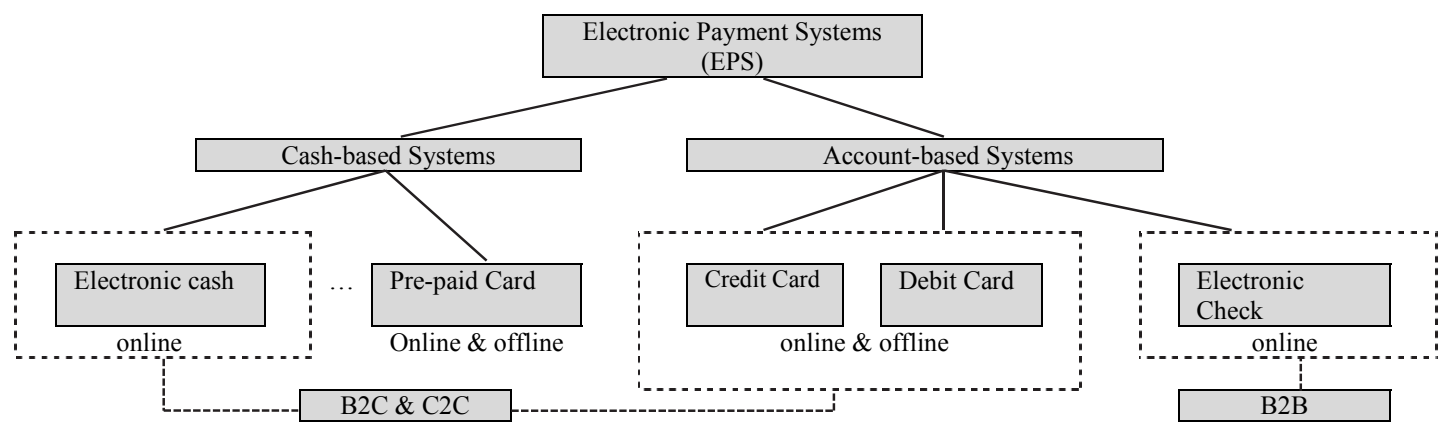

Fig. 2. Classification of electronic payment systems (Kim et al., 2010)

This payment system is most reliable and trustworthy. E-logistic companies may design their website by executing this payment system which can build trust among e-logistic users. Hence, website design is most important to promote e-logistic firm's performance.

$\boldsymbol{H}_{2}:$ There is a relationship between website design and firm's e-logistic performance.

Sufficient information technology (IT) turns out to be necessary to facilitate logistics processes (LaLonde \& Masters, 1994). Information technology (IT) may help various automate routine logistics practices, accordingly, empowering managers to focus on strategic issues as well as different fundamental competencies. Few studies from literature have reported that information technology (IT) can enhance logistical efficiency, effectiveness, cost, productivity, flexibility, and service quality (Bhatnagar et al., 1999; Closs et al., 1997; Daugherty et al., 1995; Lunce \& Smith, 2000; Suominen \& Takala, 2006).

Meanwhile, intermediate supply chain practices such as distribution of goods can be enabled as well as supported by the use of information technology (IT) (Lewis \& Talalayevsky, 1997). In addition, information technology (IT) is critical for global logistics management, in particular to coordinate worldwide distribution of products, design of product, production of products, procurement, and inventory (Huang et al., 2001). 
However, the staff services quality of e-logistic in Pakistan is not sufficient to boost e-logistic sales. The issues related to staff service quality can be resolved through better information technology (IT) capability. As it has significant influence on service quality (Bhatnagar et al., 1999). A better information technology (IT) system can provide a road map to enhance service quality. Moreover, a better website design is also possible through good information technology (IT). As it is explained by Kidane and Sharma (2016), information technology (IT) provide facility to design websites and better availability of information. It automatically increases the firm's e-logistic performance by enhancing customer satisfaction level.

Thus, it is concluded that information technology (IT) moderates the relationship between staff service quality and firm's e-logistic performance. It also moderates the relationship between website design and firm's e-logistic performance. Hence, the current study proposed following hypotheses;

$\boldsymbol{H}_{3}$ : Firm's IT capability moderates the relationship between staff service quality and firm's e-logistic performance.

$\boldsymbol{H}_{4}:$ Firm's IT capability moderates the relationship between website design and firm's e-logistic performance.

Nevertheless, traceability is the ability to authenticate the history, location, or application of an item with documented record identification. According to ISO $(9001 ; 2000)$ traceability can be defined as, the ability to trace history, tracking both status of the product and the location data records. As the elogistic process is mostly exclusive of face to face interaction between customer and e-logistic company that is the reason it is important to have an appropriate traceability system of goods. Proper etraceability system develops a level of trust among customers and increases the satisfaction level. Increase in satisfaction level automatically enhances the e-logistic firm's performance. However, the companies in Pakistan are facing the issue of goods traceability which causes to lose the customers.

This issue could be resolved by implementing effective information communication system (ICT). As it is evident from literature that most of the companies examined to invest in information technology (IT) supported traceability (Manos \& Manikas, 2010) because it increases the level of trust (Imran et al., 2018). An effective information communication system (ICT) system provides quick response to trace the e-logistic goods which increases the trust about e-logistic system.

Most of the prior studies focused on the traceability-based quality control and mainly focused on the functions and the structure of information tracing systems (Campos \& Hardwick, 2006; Jansen-Vullers et al., 2003). As the trace of e-logistic goods through information communication system (ICT) is most reliable and trustworthy as compared to the manual system, most of the companies are focusing to develop a proper traceability system in Pakistan like Traction Control System (TCS) and Dalsey Hillblom Lynn (DHL).

Information and communication technology (ICT) application in different large logistics service enterprise have been extensively examined (see, for instance, van Hoek, 2002; Larson \& Gammelgaard, 2001; Berglund et al., 1999; Peters et al., 1998). However, in rare case any study formally documented the role of information communication technology (ICT) to enhance the traceability system. That is the reason the current study examined the mediating role of information communication technology (ICT) between traceability and firm's e-logistic performance. Finally, following hypotheses are proposed;

\section{$\boldsymbol{H}_{5}:$ There is a relationship between e-traceability and firm's e-logistic performance.}

$\boldsymbol{H}_{6}:$ There is a relationship between e-traceability and information communication technology (ICT). 
$\boldsymbol{H}_{7}:$ There is a relationship between information communication technology (ICT) and firm's e-logistic performance.

$\boldsymbol{H}_{8}$ : Information communication technology (ICT) mediates the relationship between traceability and firm's e-logistic performance.

Additionally,

$\boldsymbol{H}_{9:}$ There is a relationship between firm's IT capability and firm's e-logistic performance.

\section{Research Method}

The current study is based on e-logistic companies working in Pakistan. Data were collected from managerial staff of these companies. Moreover, by considering the problem and objectives of research, quantitative research techniques were selected (Hameed et al., 2017) as the research methodology is most crucial element of every research.

Data were collected through self-visit to the e-logistic companies. However, the 5-point Likert scale was used to conduct survey. Moreover, area cluster sampling techniques was used to collect the data. It is one of the most suitable technique when the population spread on a wide area. Therefore, to cover the whole area this sampling technique is appropriate.

To apply the area cluster sampling, whole Pakistan was divided into 5 clusters based on provinces. Thus, five clusters namely; Punjab, Sindh, Balochistan, Khyber Pakhtunkhwa and Gilgit-Baltistan were formed. After formation of clusters, 3 clusters were selected, randomly. These three clusters were Punjab, Sindh and Gilgit-Baltistan. Finally, respondents were selected randomly to collect the data.

Moreover, the sample size was selected by using Comrey and Lee (1992) recommendations. According to recommendations, "sample having less than 50 participants will observed to be a weaker sample; sample of 100 size will be weak; 200 will be adequate; sample of 300 will be considered as good; 500 very good whereas 1000 will be excellent." Therefore, in current study 300 sample size was selected.

Hence, 300 questionnaires were distributed among the managerial staff of e-logistic companies in Pakistan. From these 300 questionnaires, 238 questionnaires were returned. Among these 238 questionnaires, 9 were incomplete and excluded from the study. Thus, 229 questionnaires were used to analyze the data. The response rate after data entry was $76.33 \%$ which is appropriate to proceed the analysis. Finally, SmartPLS 3 was used as a statistical tool.

\section{Research Analysis and Results}

In the first step of analyzing the data, reliability and validity were examined. To examine the reliability, Cronbach's alpha and composite reliability was examined. Cronbach's alpha value 0.70 was considered as threshold level. Moreover, by following the instructions of Hair and Lukas (2014) stated that 0.70 threshold level for composite reliability was considered. In this study, Table 1 shows that Cronbach's alpha and composite reliability is more than 0.7. Furthermore, factor loading, and average variance extracted (AVE) was examined to check the internal consistency and convergent validity. Factor loading should be more than 0.5 (Hair et al., 2010) and AVE should be more than 0.5 (Hair \& Lukas, 2014). In the current study Table 1 and Fig. 3 shows that value for factor loading and AVE is more than 0.5. Additionally, external consistency was examined through discriminant validity as shown in Table 2. 


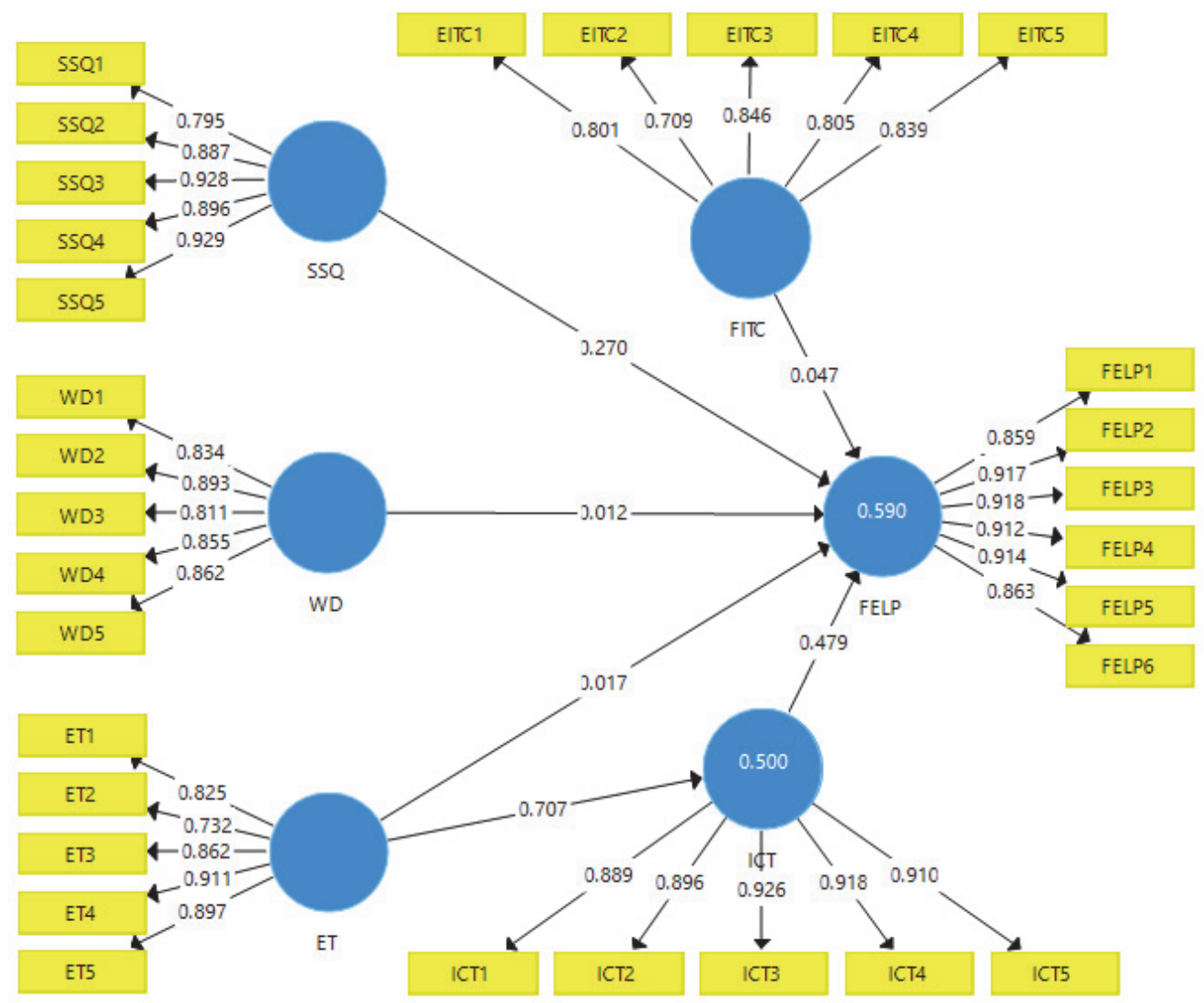

Fig. 3. Measurement Model Assessment

Table 1

Reliability and Validity

\begin{tabular}{|c|c|c|c|c|c|}
\hline Construct & Indicators & Loadings & Cronbach's alpha & Composite Reliability & AVE \\
\hline \multirow{6}{*}{$\begin{array}{l}\text { Firm's E-Logistic Performance } \\
\text { (FELP) }\end{array}$} & FELP1 & .859 & \multirow[t]{6}{*}{.952} & \multirow[t]{6}{*}{.953} & \multirow[t]{6}{*}{.806} \\
\hline & FELP2 & .917 & & & \\
\hline & FELP3 & .918 & & & \\
\hline & FELP4 & .912 & & & \\
\hline & FELP5 & .914 & & & \\
\hline & FELP6 & .863 & & & \\
\hline \multirow[t]{5}{*}{ Staff Service Quality (SSQ) } & SSQ1 & .795 & \multirow[t]{5}{*}{.933} & \multirow[t]{5}{*}{.949} & \multirow[t]{5}{*}{.789} \\
\hline & SSQ2 & .887 & & & \\
\hline & SSQ3 & .928 & & & \\
\hline & SSQ4 & .896 & & & \\
\hline & SSQ5 & .929 & & & \\
\hline \multirow[t]{5}{*}{ Website Design (WD) } & WD1 & .834 & \multirow[t]{5}{*}{.905} & \multirow[t]{5}{*}{.929} & \multirow[t]{5}{*}{.725} \\
\hline & WD2 & .893 & & & \\
\hline & WD3 & .811 & & & \\
\hline & WD4 & .855 & & & \\
\hline & WD5 & .862 & & & \\
\hline \multirow{5}{*}{ E-Traceability (ET) } & ET1 & .825 & \multirow[t]{5}{*}{.901} & \multirow[t]{5}{*}{.927} & \multirow[t]{5}{*}{.719} \\
\hline & ET2 & .732 & & & \\
\hline & ET3 & .862 & & & \\
\hline & ET4 & .911 & & & \\
\hline & ET5 & .897 & & & \\
\hline Information Communication & ICT1 & .889 & \multirow[t]{5}{*}{.947} & \multirow[t]{5}{*}{.959} & \multirow[t]{5}{*}{.824} \\
\hline \multirow{4}{*}{ Technology (ICT) } & ICT2 & .896 & & & \\
\hline & ICT3 & .926 & & & \\
\hline & ICT4 & .918 & & & \\
\hline & ICT5 & .910 & & & \\
\hline \multirow[t]{5}{*}{ Firm's IT Capability (EITC) } & EITC1 & .801 & \multirow[t]{5}{*}{.860} & \multirow[t]{5}{*}{.899} & \multirow[t]{5}{*}{.642} \\
\hline & EITC2 & .709 & & & \\
\hline & EITC3 & .846 & & & \\
\hline & EITC4 & .805 & & & \\
\hline & EITC5 & .839 & & & \\
\hline
\end{tabular}


Table 2

Discriminant Validity

\begin{tabular}{lcccccc}
\hline & $\mathbf{1}$ & $\mathbf{2}$ & $\mathbf{3}$ & $\mathbf{4}$ & $\mathbf{5}$ & $\mathbf{6}$ \\
\hline ET & $\mathbf{0 . 8 4 8}$ & & & & & \\
FELP & 0.621 & $\mathbf{0 . 8 9 8}$ & & & & \\
FITC & 0.778 & 0.640 & $\mathbf{0 . 8 0 1}$ & & $\mathbf{0 . 9 0 8}$ & \\
ICT & 0.707 & 0.738 & 0.725 & 0.754 & $\mathbf{0 . 8 0 8}$ & \\
SSQ & 0.811 & 0.694 & 0.620 & 0.766 & 0.631 & $\mathbf{0 . 8 5 1}$ \\
WD & 0.787 & 0.667 & 0.421 & & & \\
\hline
\end{tabular}

In the second step of analyzing the data, PLS bootstrapping was used to test the hypotheses which were developed through the literature. The 1.96 threshold level of t-value was considered to accept or reject the hypothesis. First of all, Table 3 shows the results of direct hypothesis. It is clear that all the relationships have t-value above 1.96 . Thus, all the direct hypotheses $\left(\mathrm{H}_{1}, \mathrm{H}_{2}, \mathrm{H}_{5}, \mathrm{H}_{6}, \mathrm{H}_{7}, \mathrm{H}_{9}\right)$ are accepted.

Table 3

Direct Effect

\begin{tabular}{clccccc}
\hline Hypothe & Relationship & $(\boldsymbol{\beta})$ & $($ STDEV) & T Statistics & P Values & Decision \\
\hline $\mathbf{H}_{5}$ & ET $\rightarrow$ FELP & 0.117 & 0.025 & 4.679 & 0.000 & Supported \\
$\mathbf{H}_{\mathbf{6}}$ & ET $\rightarrow$ ICT & 0.707 & 0.063 & 11.199 & 0.000 & Supported \\
$\mathbf{H}_{\mathbf{9}}$ & FITC $\rightarrow$ FELP & 0.147 & 0.033 & 4.453 & 0.000 & Supported \\
$\mathbf{H}_{7}$ & ICT $\rightarrow$ FELP & 0.479 & 0.168 & 2.855 & 0.004 & Supported \\
$\mathbf{H}_{\mathbf{1}}$ & SSQ $\rightarrow$ FELP & 0.270 & 0.123 & 2.202 & 0.028 & Supported \\
$\mathbf{H}_{\mathbf{2}}$ & WD $\rightarrow$ FELP & 0.092 & 0.015 & 6.133 & 0.000 & Supported \\
\hline
\end{tabular}

Table 4 shows the in-direct effect (mediation). It is evident that in-direct relationship has t-value more than 1.96 which validates the hypothesis $\mathrm{H}_{8}$. Therefore, it is proved than information communication technology (ICT) mediates the relationship between e-traceability (ET) and firm's e-logistic performance (FELP).

Table 4

In-Direct Effect

\begin{tabular}{clccccc}
\hline Hypothesis & Relationship & $(\boldsymbol{\beta})$ & $\mathbf{( S T D E V )}$ & T Statistics & P Values & Decision \\
\hline $\mathbf{H}_{\mathbf{8}}$ & ET $\rightarrow$ ICT $\rightarrow$ FELP & 0.339 & 0.115 & 2.957 & 0.003 & Supported \\
\hline
\end{tabular}

Furthermore, Table 5 shows the moderation effect. It is evident that t-value for both moderation effect is more than 1.96 which validates the $\mathrm{H}_{3}$ and $\mathrm{H}_{4}$. Thus, firm's IT capability (FITC) moderates the relationship between staff service quality (SSQ) and firm's e-logistic performance (FELP). Moreover, firm's IT capability (FITC) also moderates the relationship between website design (WD) and firm's e-logistic performance (FELP).

Table 5

Moderation Effect

\begin{tabular}{clccccc}
\hline Hypothesis & Relationship & $(\boldsymbol{\beta})$ & $\mathbf{( S T D E V )}$ & T Statistics & P Values & Decision \\
\hline $\mathbf{H}_{\mathbf{3}}$ & SSQ $\rightarrow$ FITC $\rightarrow$ FELP & 0.591 & 0.130 & 4.539 & 0.000 & Supported \\
$\mathbf{H}_{\mathbf{4}}$ & WD $\rightarrow$ FITC $\rightarrow$ FELP & 0.450 & 0.105 & 4.284 & 0.000 & Supported \\
\hline
\end{tabular}

Moreover, Table 6 shows that $\mathrm{R}^{2}$ value is 0.590 . According to Chin (1998) this $\mathrm{R}^{2}$ value is moderate. It demonstrates that five set of latent variables (staff service quality, website design, e-traceability, information communication technology, firm's IT capability) are expected to explain $59 \%$ of variance in dependent variable (firm's e-logistic performance).

\section{Table 6}

Variance Explained $\left(\mathrm{R}^{2}\right)$

\begin{tabular}{ll}
\hline Latent Variable & Variance Explained $\left(\mathbf{R}^{2}\right)$ \\
\hline Firm's E-Logistic Performance (FELP) & $59 \%$ \\
\hline
\end{tabular}


Cohen (1988) demonstrates that effect size $\left(\mathrm{f}^{2}\right) 0.02$ is small, 0.15 is moderate and 0.35 is considered as strong. However, in this study staff service quality (SSQ) has small $\mathrm{f}^{2}=0.043$, website design (WD) also has small $\mathrm{f}^{2}=0.037$. On the other hand, e-traceability (ET), information communication technology (ICT) and firm's IT capability (FITC) has moderate, moderate and strong $\mathrm{f}^{2}$ of $0.152,0.204$ and 0.360 , respectively. Results of $\mathrm{f}^{2}$ are shown in Table 7.

Table 7

Effect Size $\left(\mathrm{f}^{2}\right)$

\begin{tabular}{|c|c|c|}
\hline & f-squared & Effect Size $\left(\mathbf{f}^{2}\right)$ \\
\hline Staff Service Quality (SSQ) & 0.043 & Small \\
\hline Website Design (WD) & 0.037 & Small \\
\hline E-Traceability (ET) & 0.152 & Moderate \\
\hline Information Communication Technology (ICT) & 0.204 & Moderate \\
\hline Firm's IT Capability (FITC) & 0.360 & Strong \\
\hline
\end{tabular}

Additionally, the quality of model was examined through predictive relevance $\left(\mathrm{Q}^{2}\right)$. According to Henseler et al. (2009), $\mathrm{Q}^{2}$ value should not be less than zero. In this study $\mathrm{Q}^{2}$ is 0.443 which is more than zero. It is shown in Table 8.

\section{Table 8}

Predictive relevance $\left(\mathrm{Q}^{2}\right)$

\begin{tabular}{llll}
\hline Total & SSO & SSE & $\mathbf{Q}^{\mathbf{2}}=\mathbf{( 1 - S S E / S S O )}$ \\
\hline Firm's E-Logistic Performance (FELP) & 510.000 & 284.158 & 0.443 \\
\hline
\end{tabular}

\section{Findings}

This study examines the effect of staff service quality, website design and e-traceability system on firm's e-logistic performance. Moreover, the moderating role of firm's IT capability and mediating role of information communication technology (ICT) was examined.

It is found that staff service quality, website design and e-traceability system had significant relationship with firm's e-logistic performance with t-value $2.202,6.133$ and 4.679 , respectively. The positive $\beta$-values of $0.270,0.092$ and 0.117 were found for these direct relationships between staff service quality, website design and traceability, respectively with firm's e-logistic performance. The positive $\beta$-value shows a positive relationship between these three variables and firm's e-logistic performance. It demonstrates that a good staff service quality, appropriate website design and well managed e-traceability system had significant positive relationship with e-logistic companies performance. Improvement in all these three elements will automatically enhance the firm's e-logistic performance. Additionally, e-traceability had moderate effect 0.152 , however, staff services quality and website design had small effect 0.043 and 0.037 respectively.

Moreover, the relationship between information communication technology (ICT) with firm's elogistic performance found significant t-value 2.855 with $\beta$-value 0.479 . On the other hand, $t$-value and $\beta$-value for the relationship of firm's IT capability and firm's e-logistic performance are 4.453 and 0.147 respectively. It indicates that increase in firm's IT capability and information communication technology could enhance firm's e-logistic performance. However, the firm's IT capability had strong effect 0.360 and information communication technology (ICT) had moderate effect 0.204. Nevertheless, moderating role of firm's IT capability between staff service quality and firm's e-logistic performance found significant t-value 4.539 with $\beta$-value 0.591 . On the other hand, moderation between website design and firm's e-logistic performance found t-value 4.284 and $\beta$-value 0.450 . All these values depict that firm's IT capability had a moderating role and it enhanced the positive effect of staff service quality and website design on firm's e-logistic performance. Nonetheless, in case of mediation, it is found that information communication technology (ICT) mediates the relationship 
between e-traceability and firm's e-logistic performance. For in-direct relationship, t-value 2.957 and $\beta$-value 0.339 were found. Thus, it is found that information communication technology (ICT) as a mediating variable enhance the effect of e-traceability on firm's e-logistic performance. Therefore, information communication technology (ICT) had a vital role to establish a better e-traceability system among e-logistic companies.

\section{Conclusion}

The current study has been carried out to address the problem of low performance by logistic industry of Pakistan. This low performance was based on low staff service quality, inappropriate website design and traceability system by e-logistic companies. Therefore, the resolve this issue, the current study introduced firm's IT capability and information communication technology. Data were collected from managerial staff of e-logistic companies. All the respondents were selected from Punjab, Sindh and Gilgit-Baltistan.

Finally, the study revealed the good staff service quality, appropriate website design and well managed e-traceability system had significant effect on e-logistic companies' performance. Moreover, it has revealed that firm's IT capability had significant contribution to improve staff service quality and website design. A good IT capability provides a better communication system among employees and customers, employees and employees which can enhance the overall performance. A good IT system is one of the mandatory element to manage website in well managed design which can attract the customers. Moreover, e-traceability system can be improved through information communication technology. Customers can trace their ordered goods by using internet through good traceability system. Thus, the issue of e-traceability can be resolved through better information communication technology. Therefore, e-logistic companies should focus on firm's IT capability and information communication technology (ICT). A well-managed information technology system can resolve various issue and enhance the overall performance.

\section{References}

Barcik, R., \& Jakubiec, M. (2012). E-logistics-aspects of functioning. Acta academica karviniensia, 1. Benfang, Y., \& Feng, X. (2014). Analysis on logistics service influencing factors of C2C E-commerce customer satisfaction. Modern Business, 33-34.

Berglund, M., Van Laarhoven, P., Sharman, G., \& Wandel, S. (1999). Third-party logistics: is there a future? The International Journal of Logistics Management, 10(1), 59-70.

Bhatnagar, R., Sohal, A. S., \& Millen, R. (1999). Third party logistics services: a Singapore perspective. International Journal of Physical Distribution \& Logistics Management, 29(9), 569587.

Campos, J. G., \& Hardwick, M. (2006). A traceability information model for CNC manufacturing. Computer-Aided Design, 38(5), 540-551.

Changchit, C., Garofolo, T., \& Gonzalez, J. J. (2009). A Cultural Study of E-Commerce Trust: Hispanic Versus Anglo. Journal of Information Science \& Technology, 6(4).

Chin, W. W. (1998). The partial least squares approach to structural equation modeling. Modern Methods for Business Research, 295(2), 295-336.

Cichosz, M., Goldsby, T. J., Knemeyer, A., \& Taylor, D. F. (2017). Innovation in logistics outsourcing relationship-in the search of customer satisfaction. LogForum, 13(2).

Closs, D. J., Goldsby, T. J., \& Clinton, S. R. (1997). Information technology influences on world class logistics capability. International Journal of Physical Distribution \& Logistics Management, 27(1), 4-17.

Cohen, J. (1988). Statistical power analysis for the behavioral sciences . Hilsdale. NJ: Lawrence Earlbaum Associates, 2.

Comrey, A. L., \& Lee, H. B. (1992). A first course in factor analysis, $2^{\text {nd }}$ ed.. Hillside, NJ: Erlbaum 
Daniel, A., Ashar, M., Ihsan-Ur-Rehman, H., \& Shahbaz, W. (2012). An impact of employee satisfaction on customer satisfaction in service sector of pakistan. Journal of Asian Scientific Research, 2(10), 548-561.

Daugherty, P. J., Ellinger, A. E., \& Rogers, D. S. (1995). Information accessibility: Customer responsiveness and enhanced performance. International Journal of Physical Distribution \& Logistics Management, 25(1), 4-17.

Gummesson, E., \& Grönroos, C. (1988). Quality of services: lessons from the product sector. Add Value to Your Service, American Marketing Association, Chicago, IL.

Ha, H.Y. (2006). An integrative model of consumer satisfaction in the context of e-services. International Journal of Consumer Studies, 30(2), 137-49.

Hair Jr, J.F., \& Lukas, B. (2014). Marketing research. McGraw-Hill Education Australia.

Hair, J.F., Black, W.C., Babin, B.J., Anderson, R.E., \& Tatham, R.L. (2010). Multivariate Data Analysis. Prentice Hall.

Hameed, W. U., Azeem, M., Ali, M., Nadeem, S., \& Amjad, T. (2017). The Role of Distribution Channels and Educational level towards Insurance Awareness among the General Public. International Journal of Supply Chain Management, 6(4), 308-318.

Hameed, W. U., Nadeem, S., Azeem, M., Aljumah, A. I., \& Adeyemi, R. A. (2018). Determinants of E-Logistic Customer Satisfaction: A Mediating Role of Information and Communication Technology (ICT). International Journal of Supply Chain Management, 7(1), 105-111.

Henseler, J., Ringle, C. M., \& Sinkovics, R. R. (2009). The use of partial least squares path modeling in international marketing. In New challenges to international marketing (pp. 277-319). Emerald Group Publishing Limited.

Hsu, H. (2006). An empirical study of web site quality, customer value, and customer satisfaction based on eshop. The Business Review, 5(1), 190-193.

Hu, M., Huang, F., Hou, H., Chen, Y., \& Bulysheva, L. (2016). Customized logistics service and online shoppers' satisfaction: an empirical study. Internet Research, 26(2), 484-497.

Hua, W., \& Jing, Z. (2015). An Empirical Study on E-commerce Logistics Service Quality and Customer Satisfaction. WHICEB.

Huang, S. M., Kwan, I. S., \& Hung, Y. C. (2001). Planning enterprise resources by use of a reengineering approach to build a global logistics management system. Industrial Management \& Data Systems, 101(9), 483-491.

Hui, Y. (2011). The Study on Customer Satisfaction of Logistics Services Based on Online Shopping (Master dissertation, East China Jiao Tong University,2011). CNKI, F724.6;F259.2.

Imran, M., Aziz, A.B., Hamid, S. N. B. A., \& Hameed, W. U. (2019). The contributing factors towards e-logistic customer satisfaction: a mediating role of information Technology. Uncertain Supply Chain Management, 7(1).

Jansen-Vullers, M. H., van Dorp, C. A., \& Beulens, A. J. (2003). Managing traceability information in manufacture. International Journal of Information Management, 23(5), 395-413.

Johan, A. (2006). Sources of customer satisfaction with shopping malls: a comparative study of different customer segments. International Review of Retail, Distribution \& Consumer Research, 16(1), 115-38.

Kidane, T. T., \& Sharma, R. R. K. (2016). Factors Affecting Consumers' purchasing Decision through ECommerce. Proceedings of the 2016 International Conference on Industrial Engineering and Operations Management Kuala Lumpur, Malaysia, March 8-10, 2016, 159-165.

Kim, S. Y., \& Lim, Y. J. (2001). Consumers' perceived importance of and satisfaction with internet shopping. Electronic Markets, 11(3), 148-154.

Kim, S., \& Stoel, L. (2004). Apparel retailers: website quality dimensions and satisfaction. Journal of Retailing and Consumer Services, 11(2), 109-117.

La Londe, B. J., \& Masters, J. M. (1994). Emerging logistics strategies: blueprints for the next century. International Journal of Physical Distribution \& Logistics Management, 24(7), 35-47.

Larson, P. D., \& Gammelgaard, B. (2001). Logistics in Denmark: a survey of the industry. International Journal of Logistics, 4(2), 191-206. 
Lehtinen, U., \& Lehtinen, J. R. (1982). Service quality: a study of quality dimensions. Service Management Institute.

Lewis, I., \& Talalayevsky, A. (1997). Logistics and information technology: a coordination perspective. Journal of Business Logistics, 18(1), 141.

Lewis, R.C. \& Booms, B.H. (1983). The marketing aspects of service quality", in Berry, L.L., Shostack, C. and Upah, C. (Eds), Emerging prospectus in service marketing, American Warketing Association, Chicago, IL, pp. 99-107.

Liu, X., He, M., Gao, F., \& Xie, P. (2008). An empirical study of online shopping customer satisfaction in China: a holistic perspective. International Journal of Retail \& Distribution Management, 36(11), 919-940.

Lunce, S. E., \& Smith, S. A. (2000). A report of information technology in Mexican manufacturing firms. Industrial Management \& Data Systems, 100(5), 201-209.

Manos, B., \& Manikas, I. (2010). Traceability in the Greek fresh produce sector: drivers and constraints. British Food Journal, 112(6), 640-652.

Parasuraman, A., Zeithaml, V. A., \& Berry, L. L. (1985). A conceptual model of service quality and its implications for future research. The Journal of Marketing, 49(4), 41-50.

Parasuraman, A., Zeithaml, V. A., \& Berry, L. L. (1988). Servqual: A multiple-item scale for measuring consumer perc. Journal of retailing, 64(1), 12.

Parasuraman, A., Zeithaml, V. A., \& Berry, L. L. (1994). Reassessment of expectations as a comparison standard in measuring service quality: implications for further research. The Journal of Marketing, 58(1), 111-124.

Peters, M., Cooper, J., LIEB, R. C., \& Randall, H. L. (1998). The third-party logistics industry in Europe: provider perspectives on the industry's current status and future prospects. International Journal of Logistics Research and Applications, 1(1), 9-25.

Peterson, R. A., Balasubramanian, S., \& Bronnenberg, B. J. (1997). Exploring the implications of the Internet for consumer marketing. Journal of the Academy of Marketing science, 25(4), 329-346.

Pujani, V. (2011). Use of ecommerce websites in developing countries. World Academy of Science, Engineering and Technology, 78, 790-795.

Rana, S. S., Osman, A., \& Islam, M. A. (2014). Customer satisfaction of retail chain stores: Evidence from Bangladesh. Journal of Asian Scientific Research, 4(10), 574-584.

Shamsi, M. I., \& Syed, S. A. (2015). A study of the logistics capability factors for an e-commerce market. FAST-NU Research Journal (FRJ), 1(2), 143-149.

Suominen, M., \& Takala, J. (2006). Support of information systems to decision making: a case analysis of information needs and factors in the forest industry. International Journal of Management and Enterprise Development, 3(5), 482-490.

Thai, V. V. (2013). Logistics service quality: conceptual model and empirical evidence. International Journal of Logistics Research and Applications, 16(2), 114-131.

van Hoek, R. I. (2002). Using information technology to leverage transport and logistics service operations in the supply chain: an empirical assessment of the interrelation between technology and operations management. International Journal of Information Technology and Management, 1(1), 115-130.

Xin, L., \& Bo, Y. (2004). Service Quality Evaluation of characteristics and service recovery strategies [J]. Management Science, 6, 72-76.

Yuanxiao, Z. (2014). A study of evaluation logistic perceived services quality in B2c e-commerce (Master dissertation, Donghua University,2014). CNKI, F724.6.

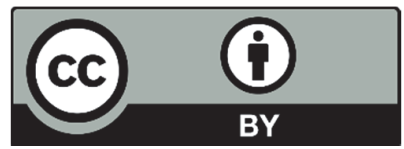

(C) 2018 by the authors; licensee Growing Science, Canada. This is an open access article distributed under the terms and conditions of the Creative Commons Attribution (CC-BY) license (http://creativecommons.org/licenses/by/4.0/). 